\title{
Geoconservation, history of
}

The word "geoconservation" was probably used for the first time in Tasmania (Australia) in the beginning of the 1990s (Sharples 1993). Sharples, a pioneer of Australian geoconservation, reports that during the period of 1993-1994, the Forestry Commission of Tasmania prepared several reports with preliminary inventories of landforms in the state forests of Tasmania in order to facilitate "the conservation of Earth systems ('Geoconservation')" (Sharples 1993). However, initiatives to protect particular geological and geomorphological features started centuries before, during the seventeenth century. The first example of the protection of geological features dates back to 1668, concerning the protection of the Baumannshöhle cave in the Harz Mountains in Germany (Grube 1994). During the nineteenth century, Germany continued to protect geology, and some other countries such as Denmark, Switzerland, and Belgium initiated the protection of certain localities, mostly for their striking geomorphological features (Erikstad 2008). In 1819, legal actions were taken to prevent impacts on the city landscape due to quarrying of stone from Salisbury Crags in Edinburgh, Scotland (Gray 2013). In Britain, the Lepidodendron stumps of "Fossil Grove" in Glasgow have been protected since their discovery in 1887; at about the same time, the "Agassiz Rock" (a striated rock surface due to the effects of the passage of glacier ice) was also preserved in Edinburgh (Black 1988). The Yellowstone National Park established in 1872 in the USA is considered the first formal protected area. The establishment of protected areas quickly expanded to other countries during the twentieth century, but most of the time geoconservation actions were not considered a priority by park managers (Brilha 2002).

The first public institution devoted specifically to geoconservation was perhaps the one created in Great Britain in the mid-twentieth century. In 1949, the approval of the National Parks and Access to the Countryside Act was the first step toward the establishment of the Nature Conservancy, the world's first statutory nonvoluntary conservation body, which included the conservation of geological and geomorphological features in its role (Prosser 2012). This initiative led to the first full-time professional role in geoconservation, a role filled in 1950 by an experienced geologist, W. A. Macfadyen, and held by him for 10 years until his retirement in 1960 (Prosser 2012). In 1977, the Nature Conservancy established the Geological Conservation Review, setting the background for the implementation of geosites conservation by means of a scientific-based methodology (Wimbledon 1988). The aim of the Geological Conservation Review was to "assess systematically the scientific part of the geological heritage of Great Britain and to select for conservation those localities that exceed a minimum threshold in their national (British) value to Earth science" (Ellis 2008). The UK played an important role in the establishment of the first methods aiming at the national-scale systematic inventory of geosites with scientific value. These methods were adapted in several other countries, particularly in Europe. International institutions started to deal with geoconservation issues in the 1970s. The UNESCO's "Convention Concerning the Protection of the World Cultural and Natural Heritage" signed in Paris in 1972 was the first international effort to select sites of paramount world importance due to their natural characteristics. Presently, $\sim 200$ sites are inscribed in the World Heritage List for their natural properties, and one third of them were selected mainly due to their geological significance. UNESCO is also linked to geoconservation through geoparks. Geoparks are well-defined territories with a development plan that aims at integrating geoconservation with the preservation of local communities' cultural identity. Based on the conservation of natural and cultural assets and on the promotion of education and geotourism, geoparks are designed to promote the sustainable development of local populations (McKeever et al. 2010). A Global Network of National Geoparks (GGN) has been set up under the auspices of UNESCO since 2004, and it integrates today 111 geoparks from 32 countries. The International Union of Geological Sciences (IUGS) created the project "Global Geosites" in 1996 aiming at the inventory of geosites with worldwide scientific importance (Wimbledon et al. 1999). However, this project was closed in 2003 by the IUGS without reaching the main goals initially expected. Since 1970, the IUGS's International Commission on Stratigraphy has identified and protected global stratotypes, which are localities with world scientific relevance to understand the Earth's time scale (GSSP, Global Boundary Stratotype Section and Point). More recently, in 2011, a new Geoheritage Task Group was created by the IUGS. The International Geographical Union (IGU) has a Commission on Geoparks since 2008 with a vision to promote the development of geoparks from a geographical perspective. The International Union for Conservation of Nature (IUCN) has approved two resolutions in 2008 and 2012 stressing the importance of geodiversity in nature and the need to protect geoheritage. In 2013, a new Geoheritage Specialist Group was created under the scope of the IUCN's World Commission on Protected Areas. The European Association for the Conservation of the Geological Heritage (ProGEO) was created in 1993, and it comprehends today the national groups in most European countries (Wimbledon and Smith-Meyer 2012). ProGEO evolved from "the European Working Group on 
Earth-Science Conservation," which was created during a workshop in Leersum (the Netherlands) in 1988. Presently, ProGEO is the most important international NGO concerning geoconservation and an active member of IUGS and IUCN. In 2001, the International Association of Geomorphologists created the working group "Geomorphological Sites: research, assessment and improvement" (the name was later changed to "Geomorphosites: research, protection and education"). This active group has been promoting scientific events, courses, and publications, mainly dedicated to the conservation and management of geomorphological heritage.

On the national level, geoconservation is being pushed forward by several types of institutions, namely, geological surveys (Albania, Argentina, Brazil, Chile, Denmark, Finland, Greece, Spain, Sweden, etc.), universities and research institutes (Bulgaria, France, Iceland, Italy, Morocco, Portugal, Romania, Spain, Switzerland, etc.), official institutions dedicated to nature conservation (China, Norway, Poland, Serbia, the UK, the USA, etc.), and NGOs (Croatia, Portugal, Turkey, the UK, etc.).

The last decade of the twentieth century marked the beginning of international meetings focused on geoconservation. The "First International Symposium on the Conservation of our Geological Heritage" held in Digne (France) in 1991 was attended by over 100 specialists from more than 30 countries. This event is considered a landmark of international discussions on geoconservation. The proceedings of the second international conference organized in Malvern (UK) in 1993 are a reference document with international impact (O'Halloran et al. 1994). So far, ProGEO has organized seven international symposia since its foundation in 1993, and the Global Geoparks Network organizes a general conference every 2 years since 2004. Every 4 years, the International Geological Congress hosts geoconservation thematic sessions, at least since the 32nd convention held in Florence (Italy) in 2004.

Some recent developments in geoconservation education and training are worth mentioning. The University of Minho (Portugal) offers a master's degree on geological heritage and geoconservation since 2005 (Brilha et al. 2012). A growing number of universities worldwide are offering courses on different subjects related to geoconservation, either as master or PhD studies. Summer courses joining students and experts in different areas of geoconservation are also organized in many countries for the last decade.

A reference set of papers on the history of geoconservation was published in 2008 by the Geological Society of London (Burek and Prosser 2008). Much more information about initiatives that belong to the history of geoconservation is available, but it remains published in only national languages; this is an obstacle to worldwide recognition.

\section{Cross-References}

- Geoconservation Policy

- Geoconservation, Concept of

- Geodiversity

- Geosite, Concept of

- Geosites, Classification of

\section{References}

- Black G (1988) Geological conservation: a review of past problems and future promise. In: Crowther PR, Wimbledon WAP (eds) The use and conservation of palaeontological sites, vol 40, Special papers in palaeontology. Palaeontological Association, London, pp 105-111

- Brilha J (2002) Geoconservation and protected areas. Environ Conserv 29:273-276

- Brilha J, Pereira D, Pereira P (2012) Geoconservation education, research and outreach: the experience of the University of Minho (Portugal). Geologia dell'Ambiente, Società Italiana di Geologia Ambientale, Supplemento al n. 3/2012:191-192

- Burek CV, Prosser CD (eds) (2008) The history of geoconservation, vol 300, The Geological Society, London, special publication, p 312

- Ellis N (2008) A history of the geological conservation review. In: Burek CV, Prosser CD (eds) The history of geoconservation, vol 300. The Geological Society, London, pp 123-135

- Erikstad L (2008) History of geoconservation in Europe. In: Burek CV, Prosser CD (eds) The history of geoconservation, vol 300. The Geological Society, London, pp 249-256

- Gray M (2013) Geodiversity: valuing and conserving abiotic nature, 2nd edn. Wiley-Blackwell, Chichester, p 495 
- Grube A (1994) The national park system in Germany. In: O'Halloran D, Green C, Harley M, Stanley M, Knill J (eds) Geological and landscape conservation. Geological Society, London, pp 175-180

- McKeever P, Zouros N, Patzak M, Weber J (2010) The UNESCO global network of national geoparks. In: Newsome D, Dowling R (eds) Geotourism: the tourism of geology and landscape. Goodfellow, Oxford, pp 221-230

- O'Halloran D, Green C, Harley M, Stanley M, Knill J (eds) (1994) Geological and landscape conservation. Geological Society, London, p 530

- Prosser CD (2012) William Archibald Macfadyen (1893-1985): the 'father of geoconservation'. Proc Geol Assoc 123:182-188

- Sharples C (1993) A methodology for the identification of significant landforms and geological sites for geoconservation purposes. Report to the forestry commission, Tasmania, $p$ 31. Available at http://eprints.utas.edu.au/11747/

- Wimbledon WAP (1988) Palaeontological site conservation in Britain: facts, form, function, and efficacy. In: Crowther PR, Wimbledon WA (eds) The use and conservation of palaeontological sites, vol 40, Special papers in palaeontology. Palaeontological Association, London, pp 41-55

- Wimbledon WAP, Smith-Meyer S (eds) (2012) Geoheritage in Europe and its conservation. ProGEO, Oslo, p 405

- Wimbledon WAP, Andersen S, Cleal CJ, Cowie JW, Erikstad L, Gonggrijp GP, Johansson CE, Karis LO, Suominen V (1999) Geological World Heritage: GEOSITES - a global comparative site inventory to enable prioritisation for conservation. Memorie Descrittive della Carta Geologica d'Italia 54:45-60

\section{Geoconservation, history of}

Dr. José Brilha Institute of Earth Sciences, Pole of the University of Minho, Braga, Portugal

DOI: $\quad$ 10.1007/SpringerReference_385487

URL: $\quad$ http://www.springerreference.com/index/chapterdbid/385487

Part of: $\quad$ Encyclopedia of Mineral and Energy Policy

Editors: Günter Tiess, Tapan Majumder and Peter Cameron

PDF created on: $\quad$ March, 05, 2015 04:09

(C) Springer-Verlag Berlin Heidelberg 2015 